Dr. Diego Ramirez Mesec

Pontificia Universidad Católica del Ecuador

@ dramirez@fabara.ec

Dr. James E. Keeble

University of Minnesota

@ jkeeble@fabara.ec
Recibido / Received 11 de octubre de 2018

- Aceptado / Acepted 28 de enero de 2019

- Páginas / Pages De la 151 a la 156

- ISSN: 2531-0054

\title{
Promoting investment and developing production in Ecuador
}

Promoviendo el desarrollo productivo e inversiones en Ecuador

This legislative review presents a summary of the Ley Orgánica para el Fomento Productivo, Atracción de Inversiones, Generación de Empleo y Estabilidad y Equilibrio Fiscal (the «Law to Foster Production») published in «Registro Oficial Suplemento» No. 309 of August 21, 2018 that provides certain tax and other incentives. The rationale behind the law is to amend the legal framework to foster an increase production, attract foreign direct investment ${ }^{1}$ and stimulate job creation.

Among the benefits introduced by the Law to Foster Production, is the remission of $100 \%$ interest, fines and other charges stemming from overdue obligations ${ }^{2}$ to IRS, Social Security, customs, basic utilities by State-owned enterprises and other State entities. There is a 90-day term given to all debtors to pay principal from the overdue obligations and be exempt from interest, fines and other surcharges. In some cases, the debtor may request to pay principal in installments (up to three years).

KEY WORDS: basic industries, bilateral investment agreement, foreign investment, incentive, exit currency tax, legal tax stability, income tax, windfall tax, new investment, productive investment, public-private partnerships and special economic development areas.

Este análisis legislativo presenta una revisión de la Ley Orgánica para el Fomento Productivo, Atracción de Inversiones, Generación de Empleo y Estabilidad y Equilibrio Fiscal (en adelante Ley de Fomento Productivo), publicada en el Registro Oficial, suplemento número 309, del 21 de agosto de 2018, que entre sus beneficios proporciona ciertos incentivos fiscales. El objetivo de la ley es modificar el marco jurídico para fomentar el aumento de la producción, atraer la inversión extranjera directa y estimular la creación de empleo.

1. Foreign Investment. Investment that is owned or controlled by foreigners domiciled abroad, or that involves capital that was not generated in Ecuador. See Article 13 (c) of the Código Orgánico de la Producción, Comercio e Inversiones, COPCI. Registro Oficial Suplemento 351, Published on December 29, 2010. Last modification on August 21, 2018.

2. Overdue obligations as of April 2, 2018. 
Entre los beneficios introducidos por la Ley de Fomento Productivo, se encuentran los siguientes: la condonación del $100 \%$ de los intereses, multas y otros cargos derivados de las obligaciones vencidas con el SRI, la Seguridad Social, la Aduana, los servicios básicos de las empresas estatales y otras entidades del Estado. Se prevé un plazo de 90 días para que todos los deudores paguen el principal de las obligaciones vencidas y estén exentos de intereses, multas y otros recargos. En algunos casos, el deudor puede solicitar el pago del capital en cuotas (hasta tres años).

PALABRAS CLAVE: industrias básicas, convenios bilaterales de inversión, inversión extranjera, incentivos, impuesto a la salida de divisas, impuesto a la renta, nueva inversión, inversión productiva, asociaciones público-privadas y zonas especiales de desarrollo económico.

\title{
Investment Aid
}

\author{
- Diego Ramirez Mesec ${ }^{3}$ \\ - James E. Keeble ${ }^{4}$
}

The new law provides aid for new ${ }^{5}$ productive $^{6}$ investments. However, there are some requirements in order to get the benefits. The investment must be initiated within 24 months of the publication of this law (August 21, 2018) (at the of the period, the President may extend the benefit for 24 months or cancel it). All income tax ${ }^{7}$ exemption periods begin when the company generates income attributable to the new investment. For existing companies, the income tax exemption will be proportional to the new investment. However, the mere transfer of assets between related parties will not be considered a new investment. Finally, for investment coming from tax havens, the benefit applies as long as their corporate information is transparent.

3. Pontificia Universidad Catolica del Ecuador J.D; John Hopkins University Master in International Public Policy (MIPP), Trade and International Finance, Foreign Service Program in International Relations (Diplomatic Academy of Ecuador). Ramirez Mesec is currently working as partner in Fabara \& Compania Abogados in Quito, Ecuador. Contact: dramirez@ fabara.ec

4. University of Minnesota (UMN) Law School J.D (Specialization) in International Law; UMN Law School (UMN) Master (LLM) in Business Law. Universidad San Francisco de Quito Lawyer. Keeble is currently working as an associate in Fabara \& Compania Abogados and faculty member at Universidad San Francisco de Quito in Ecuador. Contact: jkeeble@fabara.ec

5. New Investment. For the application of the incentives foreseen for new investments, it is understood as such the flow of resources destined to increase the capital stock of the economy, through an effective investment in productive assets that allows to expand the future production capacity, to generate a higher level of production of goods and services, or job creation, in the terms that are foreseen in the regulation. The mere change of ownership of productive assets that are already in operation, as well as the loans to acquire these assets, do not imply new investment for the purposes of COPCl. For the non-tax aspects contemplated in this Code, new investment is also considered to be any investment made for the implementation of public projects under the modality of public-private partnership. See: Article 13 (b) of the Código Orgánico de la Producción, Comercio e Inversiones, COPCI. Registro Oficial Suplemento 351, Published on December 29, 2010. Last modification on August 21, 2018.

6. Productive Investment. Productive investment, regardless of the types of ownership, is understood as the flow of resources destined to produce goods and services, expand production capacity and job creation in the national economy. Ibid. See: Article 13 (a).

7. Income Tax - a tax on the net income of an individual or a business. Mirriam Webster Dictionary, Available at: https://www.merriam-webster.com/dictionary/incentive (last visit on September 17, 2018). 


\section{A. Direct tax incentives ${ }^{8}$}

\section{Income Tax Exemption}

An exemption for new productive investments, targeting specific economic sectors (SES), ${ }^{9}$ applies to income tax («IT», including IT advance payment), ${ }^{10}$ for a period of 8 years in Quito and Guayaquil, or 12 years elsewhere. The tax benefit will also apply to existing businesses but only for new investments, if an increase of the number of jobs can be proven (net employment).

\section{Impuesto a la salida de divisas (Exit Currency Tax) ${ }^{11}$}

New productive investments are eligible for an exemption of the Impuesto de Salida de Divisas (Exit Currency Tax, ${ }^{12}$ «ISD») upon entering into an Investment Agreement with the Republic (Ministry of International Trade and Investments), on payments made abroad for imports of capital goods and raw materials. The amount is limited in the IA. The investor will need to show a foreign income source for the investment.

Existing businesses reinvesting at least $50 \%$ of their proceeds may also be eligible. This benefit does not apply to private financial businesses and strategic areas.

Also, ISD changes include:

i) The payments in compensation (set-off of mutual obligations) with foreign entities shall no longer cause ISD;

ii) Exporters will be entitled to an ISD reimbursement on payments for imports of raw materials, inputs and capital goods to be incorporated into productive processes (this applies when the parties have an Investment Agreement), and;

iii) A gradual reduction of ISD will be considered by the Administration.

8. Incentive - something that incites or has a tendency to incite to determination or action. Ibid. Mirriam Webster.

9. The Specific Economic Sectors benefited by this incentive are: a) Agriculture; Production of fresh, frozen and industrialized foods; b) Forest and agroforestry chain and its processed products; c) Metalworking; d) Petrochemical and oleochemical industries; e) Pharmaceutical; f) Tourism, cinematography, audiovisuals and international events; g) Renewable energies including bioenergy or energy from biomass; h) Logistics services for foreign trade; i) Applied Biotechnology and Software; j) Services export: The benefit will be applied to the terms and conditions provided in the regulations; k) Development and software services, production and development of hardware, digital infrastructure, cyber security, products and digital content, and online services; I) Energy efficiency: energy efficiency service companies; m) Sustainable materials and construction technologies industries; and, n) The areas of strategic substitution of imports and promotion of exports, which by Executive Decree the President of the Republic determines, based on the recommendations issued by the Sectoral Production Council. 10. In Ecuador, corporations must file and pay an «advance IT payment» equivalent to $50 \%$ of IT on the previous year (or under a special formula), which can be redeemed at filing of actual IT but if the advance payment exceeds actual IT due, this amount could be refunded. Servicio de Rentas Internas del Ecuador, Información sobre impuestos, Determinación del anticipo, more information available at: http://www.sri.gob.ec/web/guest/determinacion-del-anticipo1. (las visit on September 17, 2018).

11. Exit Currency Tax (outflow tax) - Ecuador charges a 5 percent capital exit tax on capital remitted out of the country, although there are certain exemptions. Export.gov, Ecuador Country Commercial Guide, Ecuador - Foreign Exchange Controls, available at: https://www.export.gov/article?id=Ecuador-Foreign-Exchange-Controls (last visit on September 17, 2018). 12. In Ecuador entities and individuals are required to pay ISD tax (currently $5 \%$ ), for any transfer or conveyance of money abroad, whether or not through the financial system (some exceptions apply). Servicio de Rentas Internas del Ecuador, Información sobre impuestos, Impuesto a la salida de divisas ISD, more information available at: htttp://www. sri.gob.ec/web/guest/impuesto-a-la-salida-de-divisas-isd (las visit on September 17, 2018). 


\section{Income Tax Exemption for Investments in Industry}

There will be a 12-year IT exemption for investment in industrial, agro-industrial, and agrosocial businesses. If the investment is performed on strategic economic areas, or in certain basic industries, ${ }^{13}$ the exemption will be for 15 -years. However, the 15 -year term can be extended up to 5 years more, if the investment is located at the country's border area.

\section{B. Investment Agreement and Regional Arbitration}

1. Investment Agreements ${ }^{14}$ are intended to guarantee international investors legal tax stability for 15 years,,$^{15}$ provide some incentives, and may include international arbitration of investment disputes; for investment of USD 100 million or more, it can provide tax stability.

2. Regional Arbitration. For investments of USD $\$ 10$ million or more, investors will have access to national or international arbitration (with a choice of arbitration by the Court of Permanent Arbitration under UNCITRAL rules; under rules of the Paris International Chamber of Commerce; and under rules of the Inter-American Commercial Arbitration Commission or others).

\section{Special Investment Regimes}

\section{Alianzas público-privadas (PPP) ${ }^{16}$}

The new law intents to facilitate approval of projects and streamline procedures for incentives. The PPPs will have an Income Tax exemption over 10 years and deduction of payments to foreign financial institutions for financing; the ISD exemption on imports. The law also provides for the implementation of commercial trusts for the collection and management of revenues

13. Basic Industries - The State will promote basic industries taking advantage of raw materials from renewable and non- renewable natural resources, turning them into products required by other industries for the manufacture of intermediate and final products. According to Código Orgánico de la Producción This fallowing economic areas shall be understood as basic industries: a) Copper and/ or aluminum casting and refining; b) Steel foundry for the production of flat steel; c) Hydrocarbons refining; d) Petrochemical and cellulose industry; and, Construction and repair of naval vessels. See Código Orgánico de la Producción, Comercio e Inversiones - COPCI, Registro Oficial Suplemento No. 351, from December 21, 2010. Last update in August 21, 2018.

14. Bilateral Investment Agreement - is an alternative to a Bilateral Investment Treaty (BIT), all of which Ecuador terminated due to the conflict of submission of disputes to international arbitration with a Constitutional provision. The Cancilleria (Foreign Ministry) has sent proposals to sixteen countries and expects to negotiate new BIA's, an interesting alternative to attract Foreign Direct Investment.

15. Legal Tax Stability - will apply to Income Tax, Tax Rate and exemptions. Also, to ISD and in other direct taxes (excluding Sales Tax and Excise duty /tax).

16. Public-Private Partnerships - In Ecuador PPP's are established by a contract between the public (State) entity and a private investor, whereby services of public nature or function (e.g. public services or public infrastructure) are delegated to the private sector pursuant to an agreement in which the term, risk allocation and benefits for the parties are set. See: Ley Orgánica de Incentivos para Asociaciones Público Privadas, Registro Oficial Suplemento 652, Published on December 18, 2015, Last modification introduced on August 21, 2018. More information available at: https://www. obraspublicas.gob.ec/wp-content/uploads/downloads/2017/01/APP_2017_MTOP_ESP_LEY-DE-APPs.pdf. (Last visit on September 17, 2018). 
coming directly out of the projects, providing an alternative to secure future payments to investors or allowing a project investment structure for financing.

\section{Special Economic Development Areas or «ZEDE»"17}

It seeks to attract business to certain geographic areas of the country by providing additional incentives. Among the benefits are tax incentives, simplification of customs procedures and facilities for production chains.

Among the new law main contributions are: a more efficient process for approval of projects and incentives; IT exemptions for reinvestment in projects, scientific research or technology development; ISD exemption for payment of import of goods and services related to the activity and for external financing; Impuesto al Valor Agregado (Sales Tax, "IVA») credit on the purchase of raw material, supplies and services in Ecuador, and; $0 \%$ IVA on goods imported for production.

\section{Non-renewable natural resources}

The approved amendments introduce several positive changes for the industry, that will turn investment in this field more attractive and encourage its development.

a. Mining concessions (mining rights): among the changes introduced in are: new percentages and progressive calculation of mining royalties; ${ }^{18}$ and, elimination of the Windfall Tax. ${ }^{19}$

b. Oil/ Hydrocarbos: The Oil Production Sharing Contract ${ }^{20}$ is reintroduced, where the Government share (percentage) will be adjusted according to reference prices and production volume. The administration will review annually its benefits, in which case will never be lower than those of the contractor.

17. Special Economic Development Areas - in Ecuador ZEDE's are customs destinations in limited geographical areas, with tax incentives, simplification of customs procedures and productive chains in compliance with the provision of the law. Ministerio de Industrias y Productividad, ¿Qué es una ZEDE?, information available at: https://www.industrias. gob.ec/que-son-las-zede/ (Last visit on September 17, 2018).

18. New Percentages and Progressive Calculation of Mining Royalties - the new rates of royalties ranged from $3 \%$ to $8 \%$ of sales (they used to be between $5 \%$ and $8 \%$ of sales). Also, a new method for the calculation of royalties will be based on minerals price, type and mining licensee volumes of production. The introduce changes are effective since the publication of the law (August 21, 2018) and introduced benefits are also available for current operators.

19. Widfall Tax - Mining companies are subject to $70 \%$ excess of profits windfall tax. This will be determined by the sales exceeding the price fixed in the mining contract. See: Ley de Equidad Tributaria: Creación del Impuessto a los Ingresos Extraordinarios, Registro Oficial Suplemento No. 242, Published on December 29, 2007. Last modification introduced on August 21, 2018. Also, it was incorporated into article 40 of the Ley de Minería, Registro Oficial Suplemento No. 517, Published on January 29, 2009, Last modification introduced on August 21, 2018.

20. Oil Production Sharing Contract - this contract was recently reintroduced by Presidential Decree No. 449. Which includes; a) a new calculation for participation, based on reference price and crude oil quality; b) state's minimum participation of $12.5 \%$ of total audited production; c) clarification of reference price, which is the weighted average of price of oil sales made the prior month; and, d) there will be an annual review of profits in which those of the contractor should never be more than the State profits (an special formula will publish to solve the issue). Decreto Ejecutivo No. 449, Registro Oficial Suplemento No. 291, published on July 25, 2018. 


\section{E. Public Debt Ceiling Waiver}

The $40 \%$ public debt to GDP ceiling is waived for the $2018-2021$ period.

\section{F. Budget without primary deficits}

The law establishes that no State Budget will be approved with a primary deficit.

\section{G. Stability Fund}

This law creates a fiscal stabilization fund to ensure fiscal sustainability and health and education expenses, supported by the extra revenue above the flows contemplated under the Budget from the exploitation of non-renewable natural resources, after deducting the share earmarked to local governments.

\section{Comments}

I. The Ecuadorian Business Committee Comité Empresarial Ecuatoriano considers the new law as a «Great Step» toward achieving a sustainable development of the economy and for jobs creation. Some introduced aid, will boost businesses facing a financial hard time, leaving more liquidity for job creation and entrepreneurial initiatives.

II. With the new investment and production framework, FDI is expected to increase during 2018/19, and reach about US\$ 15 billion. The country has a USD 33 billion investment portfolio, that is being aggressively promoted by the government. This trend is forecasted to continue in president Moreno's coming 3 years, with further political stability, independence of the judiciary, governmental measures to improve investment climate, less bureaucracy and legislative support. 